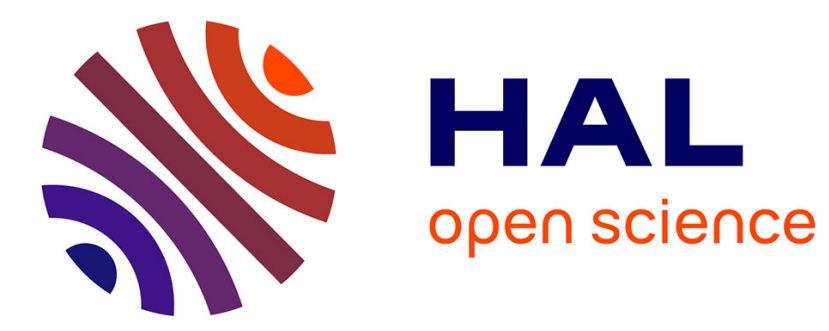

\title{
Electrical Faults Modeling of the Photovoltaic Generator
}

Wail Rezgui, Leila-Hayet Mouss, Nadia Kinza Mouss, Mohamed Djamel

Mouss, Yassine Amirat, Mohamed Benbouzid

\section{To cite this version:}

Wail Rezgui, Leilla-Hayet Mouss, Nadia Kinza Mouss, Mohamed Djamel Mouss, Yassine Amirat, et al.. Electrical Faults Modeling of the Photovoltaic Generator. International Review on Modelling and Simulations, 2014, 7 (2), pp.245-257. hal-01017387

\section{HAL Id: hal-01017387 \\ https://hal.science/hal-01017387}

Submitted on 2 Jul 2014

HAL is a multi-disciplinary open access archive for the deposit and dissemination of scientific research documents, whether they are published or not. The documents may come from teaching and research institutions in France or abroad, or from public or private research centers.
L'archive ouverte pluridisciplinaire HAL, est destinée au dépôt et à la diffusion de documents scientifiques de niveau recherche, publiés ou non, émanant des établissements d'enseignement et de recherche français ou étrangers, des laboratoires publics ou privés. 


\title{
Electrical faults modeling of the photovoltaic generator
}

\author{
Wail Rezgui ${ }^{1}$, Leïla-Hayet Mouss ${ }^{1}$, Kinza Nadia Mouss ${ }^{1}$ \\ Mohamed Djamel Mouss ${ }^{1}$, Yassine Amirat ${ }^{2}$ and Mohamed Benbouzid ${ }^{3}$
}

\begin{abstract}
In this paper, we presented a new methodology for the mathematical modeling of the photovoltaic generator's characteristics based on known electrical laws. This proposed new methodology in this work consists of a three new algorithms, each one presents the characteristic of the cell, group of cells, module, string and generator, when one or more of its components : cells, bypass diodes and blocking diodes subjected to these types of defaults: reversed polarity, open circuit, short circuit or impedance. The three new algorithms obtained can facilitate the prediction for the prognosis or the detection for the diagnosis of these photovoltaic generator's defaults.
\end{abstract}

Keywords: photovoltaic generator, I-V characteristic, modeling, simulation, reversed polarity, open circuit, impedance and short circuit faults.

\section{Nomenclature}

$\begin{array}{ll}\text { PV } & =\text { Photovoltaic generator } \\ \text { String } & =\text { Photovoltaic string. } \\ \text { Module } & =\text { Photovoltaic module. } \\ \text { Group } & =\text { Photovoltaic group. } \\ \text { Cell } & =\text { Photovoltaic cell. }\end{array}$

$n c: n c g / n c p=$ Cell number: good / defective

$n g: n g g / n g p=$ Group number: $\operatorname{good} /$ defective.

$n m: ~ n m g / n m p=$ Module number: good / defective.

$n s: n s g / n s p=$ String number: good / defective.

$n f g / n f p \quad=$ Good $/$ defective generator.

$N_{\text {Cells }} \quad=$ Number of cells in each group.

$N_{\text {Groups }} \quad=$ Number of groups in each module.

$N_{\text {Modules }} \quad=$ Number of modules in each string.

$N_{\text {Strings }} \quad=$ Number of strings in each generator.

$V \quad=$ Voltage.

$I \quad=$ Current.

$P \quad=$ Power.

$I_{\text {Bypass }}=$ Bypass current.

$V_{\text {Cell_imposed }}=$ Voltage imposed.

$V_{\text {Cell_open-circuit }}=$ Cell open circuit voltage .

$I_{\text {Cell_Short-circuit }}=$ Cell short circuit current.

phi $^{-} \quad=$ Sunlight

phi $i_{S C} \quad=$ Sunlight standard condition.

$i p h_{S C} \quad=$ Photo current standard condition.

$t_{n f} \quad=$ Normal functioning temperature.

$t c_{S C} \quad=$ Cell temperature standard condition.

at $\quad=$ Ambient temperature.

$R_{s} \quad=$ Cell series resistance.

$R_{s h} \quad=$ Cell shunt resistance.

$I_{0} \quad=$ Reverse saturation current of the diode.

$d t v \quad=$ Diode thermal voltage.

Alpha = Temperature coefficient of the short-

circuit current.

\section{Introduction}

The productivity of photovoltaic generators is based on two main factors [1-3]: solar radiation energy which is captured by the generator and direct electrical energy resulting from the conversion of the solar radiation energy by the photovoltaic phenomena. So, the degradation of these two factors means the presence of a problem at the generator.

Practically, the existence of electrical defects on this type of systems can reduce its productivity, among of the major faults known in the field of its diagnosis [4-11]: the short circuit, open circuit, impedance and finally reversed polarity faults. So, these defects can reduce the power produced by the PV generator by the change of its current, voltage, resistance, temperature and sunlight. For this and with the rising costs of photovoltaic generators, it is better to predict and maintain the faulty components before its unavailability.

The paper's objective is the development of a model able to predict the abnormal situations of the PV generator functioning [12-22]. Our contribution presented in this paper is to propose a new methodology for modeling the photovoltaic generator, based 1) on the mathematical modeling of the IV characteristic of its faulty components which can be: cells, bypass diodes and blocking diodes, for objective to study the functioning of these faulty elements itself, and 2) this new methodology based also on the mathematical modeling of the IV characteristic of the generator's groupings, which can grouped these faulty elements: cell, cells' group, module, string and finally the PV generator, for objective to study the influence of these faulty components on the functioning of these groupings. 


\section{Modeling the photovoltaic generator in normal functioning}

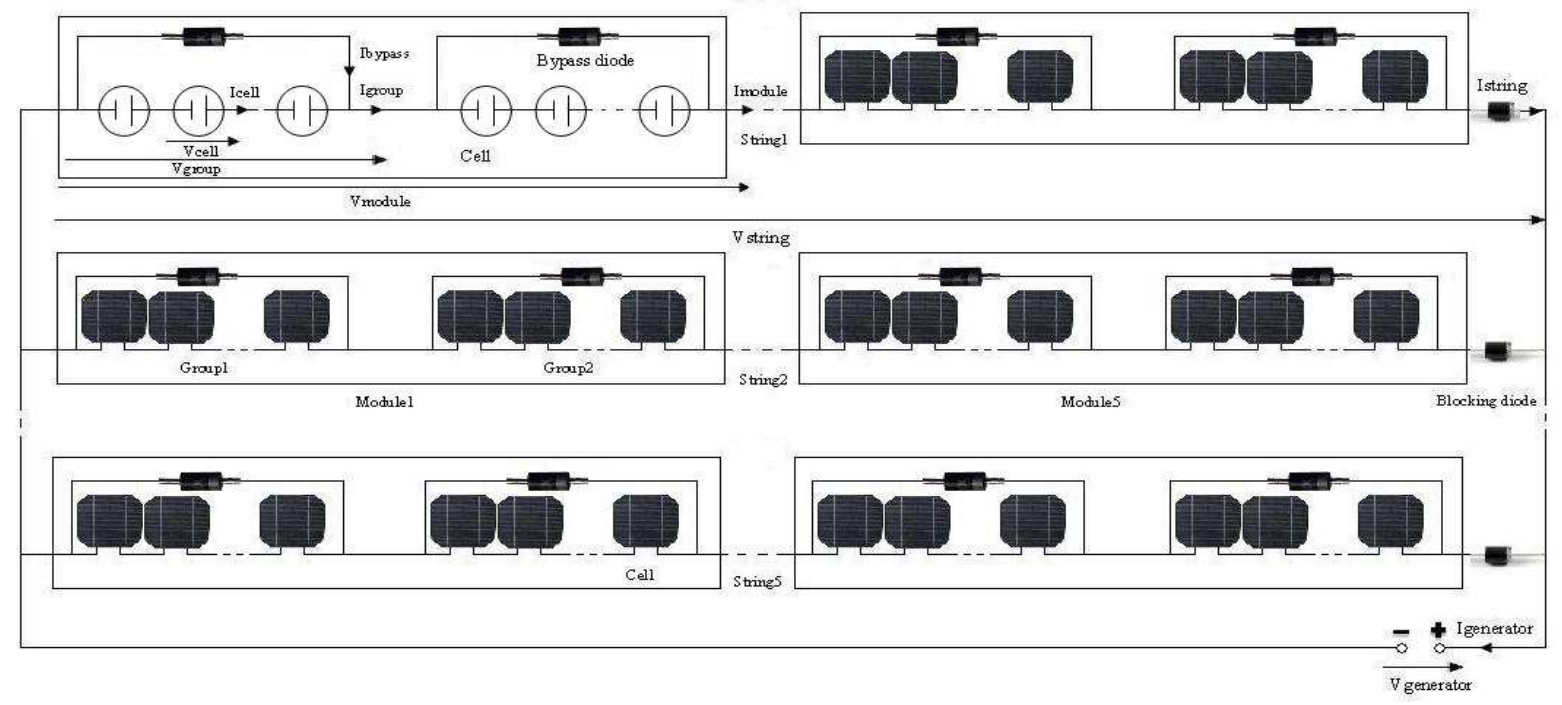

Fig1. Electrical block diagram of a photovoltaic generator in its normal functioning

Modeling of the PV generator in its proper functioning presented in this work, is for objective to make a comparison of the results thereafter, between the normal case and the abnormal cases, this comparison may facilitate the detection of any defect can degrade the productivity of a photovoltaic generator.

To test the performance of the mathematical models presented in this article, we used a generator figure 1 consists of five parallel strings, each terminated with a blocking diode and contain five photovoltaic modules in series, where each module is formed with two groups of photovoltaic cells, and finally each group contains eighteen cells regrouped by one bypass diode.

Because, we have used in the modeling of the generator's cells the "a diode model, so the mathematical modeling of the I-V characteristic of the generator in the normal function is

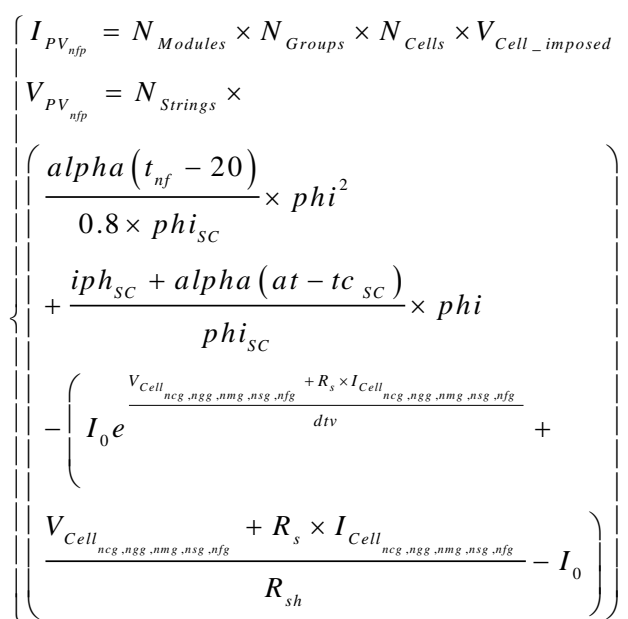

Figure 2 shows the IV characteristic and the power of a good photovoltaic generator.

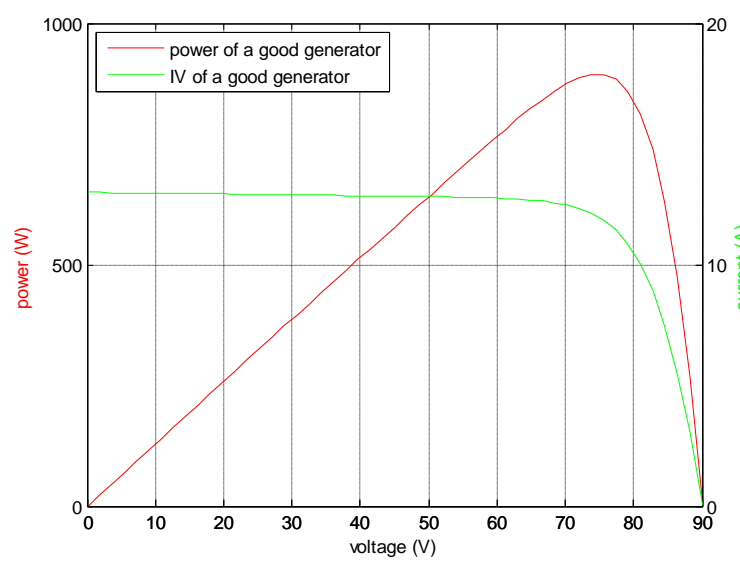

Fig2. Power and IV of a good PV generator

\section{Modeling the photovoltaic generator in malfunctioning}

\section{III.1. Cell defects}

III.1.1. At the level of the PV cell

a) For the reversed polarity default

A cell reversed polarity provides

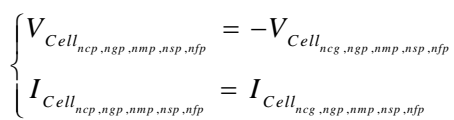

b) For the open circuit default

Because the cell is presented as a generator, so his characteristic when subjected to the open circuit default is 
$\left\{\begin{array}{l}V_{\text {Cell }}=V_{\text {cep nngp,nmp,nsp,nfp }}=V_{\text {Cell }} \text { open-circuit } \\ I_{\text {Cell }}=0\end{array}\right.$

c) For the impedance default

A cell is subjected to the impedance fault if

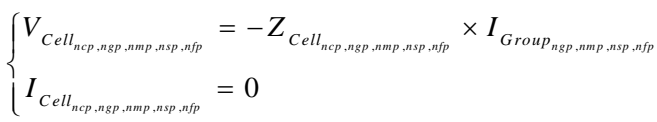

d) For the short circuit default

A photovoltaic cell is short circuited if

$\left\{\begin{array}{l}V_{\text {Cell }_{n c p, n g p, n m p, n s p, n f p}}=0 \\ I_{\text {Cell }_{n c p, n g p, n m p, n s p, n f p}}=I_{\text {Cell__Short-circuit }}\end{array}\right.$

\section{III.1.2. At the level of the PV group}

a) For the reversed polarity default

The faulty PV group's voltage contains cells reversed polarity is

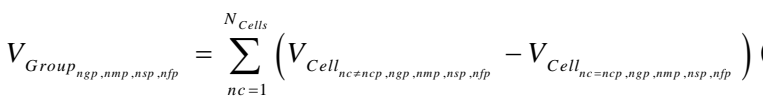

But the group's current is dependent to its voltage, for that, if its voltage is positive

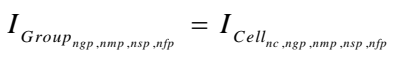

Where, the good and defective cells supplied the same currents values.

Else - if the voltage of this group is negative-, then

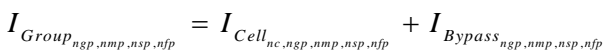

b) For the open circuit default

The existence of a single cell open circuit in a faulty photovoltaic group can cut the circulation of its current, so its characteristic is

$\left\{\begin{array}{l}V_{\text {Group }_{n g p, n m p, n s p, n f f p}}=N_{\text {Cells }} \times V_{\text {Cell_open-circuit }_{-}} \\ I_{\text {Group }_{n g p, n m p, n s p, n f p}}=I_{\text {Bypass }_{n g p, n m p, n s p, n f p}}\end{array}\right.$

c) For the impedance default

If the faulty group contains defective cells impedances, contains also at least one good cell, so the current flowing between its cells is not null, and by the voltages in series addition law

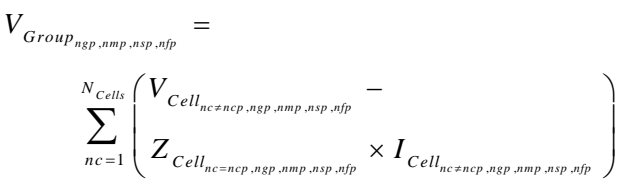

If the group's voltage is positive, then consequently it contains at least one good cell, and by the currents in series addition law

$$
I_{\text {Group }_{n s p, n m p, n s p, n f p}}=I_{\text {Cell }_{n c \neq \pi n p, n g p, n m p, n s p, n, n f p}}
$$

But if the group's voltage is negative and it contains at least one good cell, so by the currents in series addition law

$I_{\text {Group }_{n g p,, n m p, n s p, n f p}}=I_{\text {Cell }_{n c \neq n c p, n g p, n m p, n s p, n f p}}+I_{B y p a s s_{n g p, n m p, n s p, n f p}}$

The last situation, where the entire group's cells are impedances, so the current choose the easy way

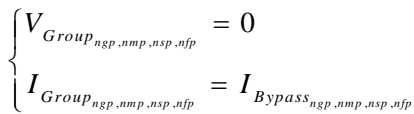

d) For the short circuit default

The IV characteristic of a faulty PV group contains defective cells short circuit is dependent on the number of its good cells existing. If it contains at least one cell is good

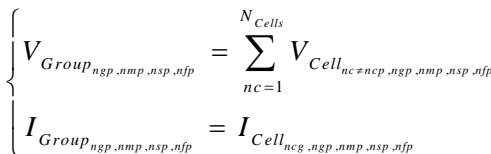

By cons, - all the group's cells are defective- and by the nodes law:

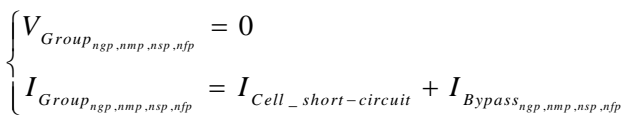

III.1.3. At the level of the PV module

a) For the reversed polarity default

So the faulty module's voltage contains cells reversed polarity is

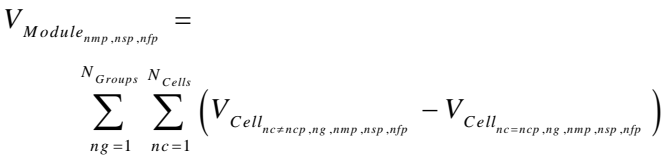

But the module's current is dependent to the voltages of each one of its groups, so if it contains at least one group with a positive voltage

If $\exists$ group ng’=1: $\mathrm{N}_{\text {Groups }}$ where Vgroup ${ }_{\text {ng }}>0$ :

$I_{\text {Modul }_{n m p, n s p, n f p}}=I_{\text {Cell }_{n c, n g=n g} ; n m p, n, s p, n f p}$

Else and by the currents in series addition law and the nodes law

$I_{\text {Module }_{n m p, n s p, n f p}}=I_{\text {Cell }_{n c, n g, n n p, n s p, n f p}}+I_{\text {Bypass }_{n g, n p p, n s p, n f p}}$

b) For the open circuit default

The IV characteristic of the faulty module depends on the number of its faulty groups existing, so if it contains at least one good group 


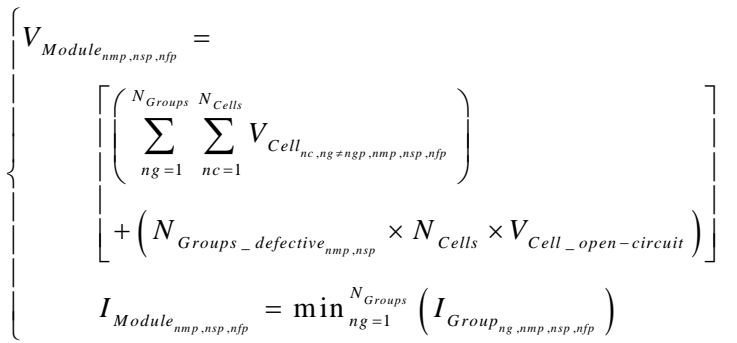

Otherwise,

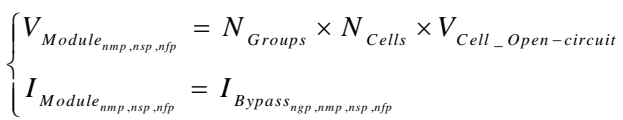

c) For the impedance default

The module's voltage contains at least one good cell is dependent to the voltages provided by its good and defective cells

If $\exists \mathrm{nc}=1: \mathrm{N}_{\text {Cells }}$ of $\square \mathrm{ng}=1: \mathrm{N}_{\text {Groups' }}$, Icell $_{\text {nc,ng,nmp,nsp,nfp }} \neq 0$

$$
\begin{aligned}
& V_{\text {Module }_{\text {nmp }, \text { nsp }, \text { nfp }}}=
\end{aligned}
$$

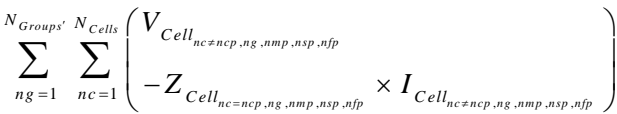

$N_{\text {Groups: }}$ : Number of groups where each one contains at least one cell is good.

But the module's current where it has at least one cell is good and by the currents in series addition law

$$
I_{\text {Module }_{n m p, n s p, n f p}}=\min _{n g=1}^{N_{\text {Groups }}}\left(I_{\text {Group }_{n g, n m p, n s p, n f p}}\right)
$$

By const, if all the module's cells are defective then: $\square \mathrm{nc}=1: \mathrm{N}_{\text {Cells }}$ of $\square \mathrm{ng}=1: \mathrm{N}_{\text {Groups }}$, Icell ${ }_{\mathrm{nc}, \mathrm{ng}, \mathrm{nmp}, \mathrm{nsp}, \mathrm{nfp}}=0$

$\left\{\begin{array}{l}V_{\text {Modul }_{n m p, n s p, n f p}}=0 \\ I_{\text {Module }_{n m p, n s p, n f p}}=I_{\text {Bypass }_{n, n, n m p, n s p, n f p}}\end{array}\right.$

d) For the short circuit default

The faulty module's characteristic, where it has at least one good cell

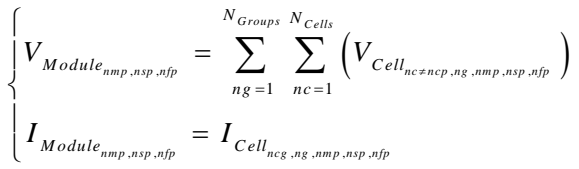

But if all its cells are defectives then

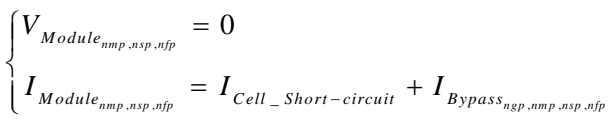

III.1.4. At the level of the PV string

a) For the reversed polarity default

The string's voltage is equal by the voltages in series addition law

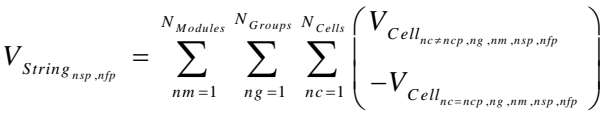

And the string's current is equal by the currents in series addition law

$I_{\text {String }_{n s p, n f p}}=\min _{n m=1}^{N_{\text {Modules }}}\left(\min _{n g=1}^{N_{\text {Groups }}}\left(I_{\text {Group }_{n g, n m, n s p, n f p}}\right)\right)$

b) For the open circuit default

The string's characteristic if it contains at least one good group



Otherwise:

$\left\{\begin{array}{l}V_{\text {String }_{n s p, n f p}}=N_{\text {Modules }} \times N_{\text {Groups }} \times N_{\text {Cells }} \times V_{\text {Cell_open-circuit }} \\ I_{\text {String }_{n s p, n f p}}=0\end{array}\right.$

And this is the problem, it is true that this default increases the voltage and even gives the maximum which is our objective, but he canceled outright the current and thus also the power.

c) For the impedance default

Also the IV characteristic of the string is depended on the number of its good and defective cells, so if it contains at least one good cell then

If $\exists$ nc $=1: \mathrm{N}_{\text {Cells }}$ of $\square \mathrm{ng}=1: \mathrm{N}_{\text {Groups' }}$ of $\square \mathrm{nm}=1$ : $\mathrm{N}_{\text {Modules }}$, Icell nc,ng,nm,nsp,nfp $_{\text {f }} \neq 0$

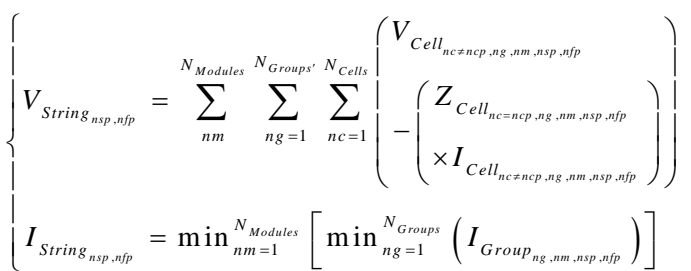

$N_{\text {Groups: }}$ : Number of groups where each one contains at least one cell is good.

By cons, if all string's cells are impedances then:

$\square \mathrm{nc}=1: \mathrm{N}_{\text {Cells }}$ of $\square \mathrm{ng}=1: \mathrm{N}_{\text {Groups }}$ of $\square \mathrm{nm}=1$ : $\mathrm{N}_{\text {Modules }}$, Icell $\mathrm{nc}_{\mathrm{nc}, \mathrm{ng}, \mathrm{nm}, \mathrm{nsp}, \mathrm{nfp}}=0$

$\left\{\begin{array}{l}V_{\text {String }_{n s p, n f p}}=0 \\ I_{\text {String }_{n s p, n f p}}=0\end{array}\right.$

d) For the short circuit default

At the string, the difference between its current and its voltage must remarkable because its current is remaining 
constant, by against its voltage increases by increasing the number of its cells. So, the IV characteristic of a faulty string contains at least one good cell

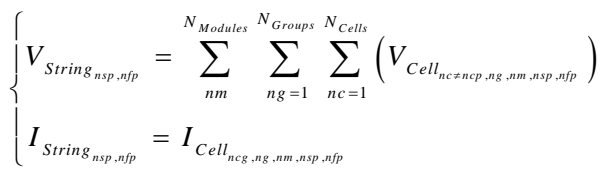

Otherwise - all its cells are short circuited-:

$$
\left\{\begin{array}{l}
V_{\text {String }_{n s, n f f p}}=0 \\
I_{\text {String }_{n s p, n f p}}=I_{\text {Cell_Short-circuit }}
\end{array}\right.
$$

\section{III.1.5. At the level of the PV generator}

a) For the reversed polarity default

Because this default can reduce the voltage of the string, then the faulty generator's voltage is dependent to its faulty strings' voltages only, but the generator's current is dependent to its good and defective strings

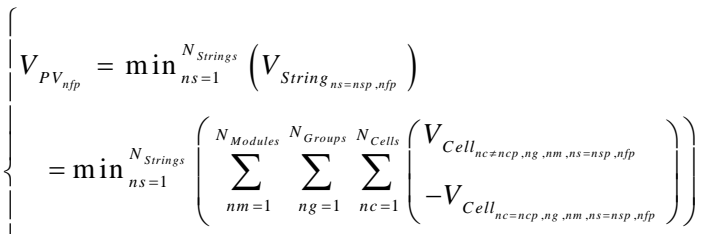

$$
\begin{aligned}
& \left.I_{P V_{n f p}}=\sum_{n s=1}^{N_{\text {Srrings }}}\left[\min _{n m=1}^{N_{\text {Modules }}}\left(\min _{n g=1}^{N_{\text {Groups }}}\left(I_{G_{\text {roup }}}\right)\right)\right)\right]
\end{aligned}
$$

b) For the open circuit default

The IV characteristic of the faulty generator is determined by the IV characteristics of its strings, so its current is dependent to its good and faulty strings which contain at least one good group and by the currents in parallel addition law

$I_{P V_{n f p}}=N_{\text {Strings }} \times I_{\text {Cell }_{n, n, n g s, n m, n s, n f p}}$

Where $N_{\text {strings': }}$ strings contain at least one good group.

And its voltage is dependent to its good strings, so if it contains at least one good string (because they have the most minimal voltage)

$$
V_{P V_{n f p}}=N_{\text {Modules }} \times N_{\text {Groups }} \times N_{\text {Cells }} \times V_{\text {Cell } l_{\text {ncg }, n g g, n u m g, n s g, n f p}}
$$

Otherwise:

$$
\begin{aligned}
& V_{P V_{n f p}}=\min _{n s=1}^{N_{\text {Srrings }}}\left(V_{\text {String }_{n s=n s p, n f p}}\right)
\end{aligned}
$$

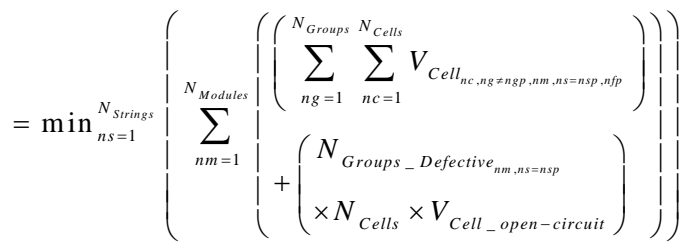

c) For the impedance default
The faulty generator's voltage is dependent to its faulty strings' voltages; because if it contains a good string, sure its voltage is greater, by cons the generator's current is dependent to its strings contained at least one cell is good.

If $\exists \mathrm{nc}=1: \mathrm{N}_{\text {Cells }}$ of $\exists \mathrm{ng}=1: \mathrm{N}_{\text {Groups' }}$ of $\exists \mathrm{nm}=1$ : $\mathrm{N}_{\text {Modules }}$ of $\exists \mathrm{ns}=1: \mathrm{N}_{\text {Strings }}$, Icell $_{\mathrm{nc}, \mathrm{ng}, \mathrm{nm}, \mathrm{ns}, \mathrm{nfp}} \neq 0$

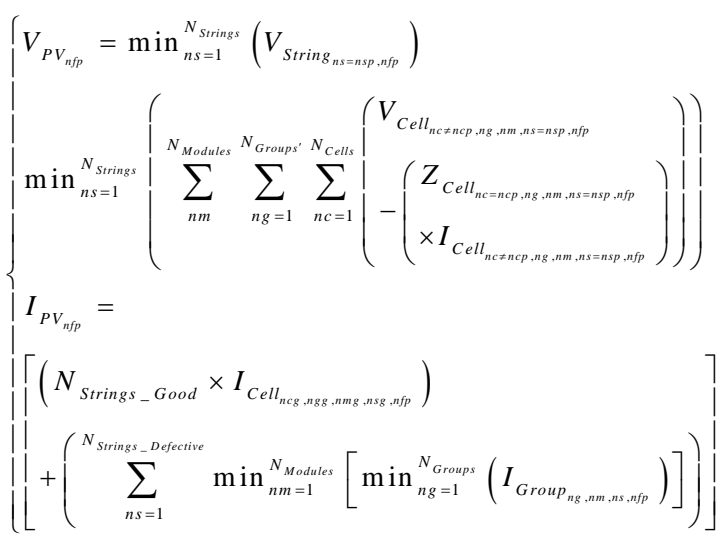

Where: $N_{\text {Groups: }}$ : Number of groups where each one contains at least one cell is good.

But if all the cells of this faulty generator are impedances, so the generator's characteristics become

$\left\{\begin{array}{l}V_{P V_{n f p}}=0 \\ I_{P V_{n f p}}=0\end{array}\right.$

d) For the short circuit default

Faulty generator's voltage depends on the number of its good and defective strings, and even the number of the good cells existing in each one of its faulty strings. But the generator's current is dependent to its good and faulty strings which contain at least one good cell:

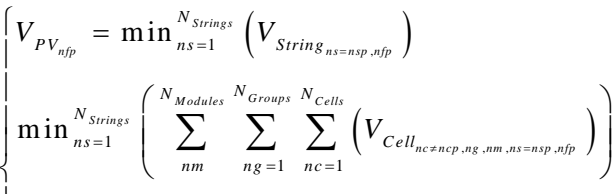

$$
\begin{aligned}
& I_{P V_{n f p}}=\left[\begin{array}{l}
\left(N_{\text {Strings }^{\prime}} \times I_{\text {Cell }_{n c g, n g, n m, n s, n f p}}\right) \\
+\left(N_{\text {Strings }^{\prime \prime}} \times I_{\text {Cell_Short-circuit }}\right)
\end{array}\right]
\end{aligned}
$$

Where:

$N_{\text {Strings }}:$ Number of strings contains at least one good cell. $N_{\text {Strings": }}$ Number of strings all its cells are defective.

\section{III.2. Bypass diode defects}

\section{III.2.1. At the level of the PV group}

a) For the reversed polarity default

As the bypass diode is reversed polarity, it can create a short circuit default at the level of its group 




b) For the open circuit default

Default bypass diode open circuit has no influence on the IV characteristic, neither photovoltaic cell, neither cells group, neither PV module, neither PV string and neither the PV generator, for this the group's characteristic is

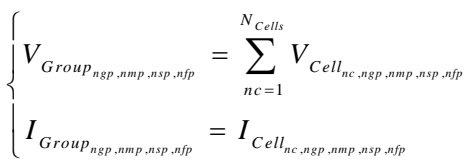

c) For the impedance default

The defect bypass diode impedance has no effect on the voltage of the photovoltaic cells protected by him, for this the group's characteristic is

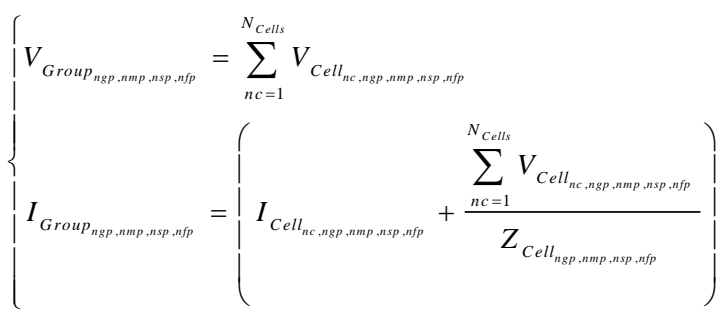

\section{d) For the short circuit default}

The influence of the faulty bypass diode short circuit on the IV characteristic of the photovoltaic cell is null, but it can create a short circuit that can cancel the faulty group's voltage, for this the group's characteristic is

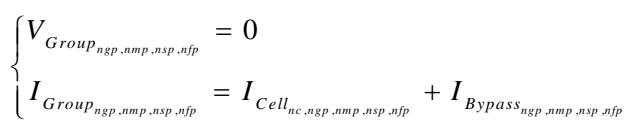

\section{III.2.2. At the level of the PV module}

a) For the reversed polarity default

This defect has an influence most remarkable on the IV characteristic of the faulty photovoltaic module, so the module's voltage is by the voltages in series addition law and because the faulty groups' voltages are null

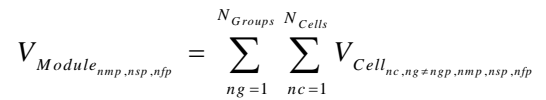

But the module's current is dependent to its faulty groups and by the currents in series addition law

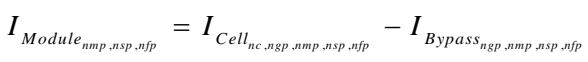

b) For the open circuit default

The characteristic of the faulty module is dependent to its good and defective groups

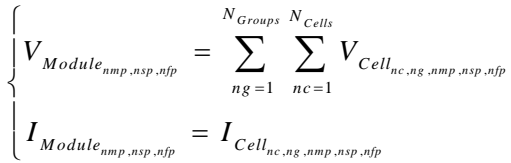

c) For the impedance default

Faulty module's voltage also does not affect by the influence of this default

$V_{\text {Module } e_{n m p, n s p, n f p}}=\sum_{n g=1}^{N_{\text {Groups }}} \sum_{n c=1}^{N_{\text {Cells }}}\left(V_{\text {Cell }_{n c, n g, n m p, n s p, n f p}}\right)$

But its current is dependent on the number of its good groups, such that if it contains at least one good group then

$I_{\text {Module }_{n m p, n s p, n f p}}=I_{\text {Cell }_{n c, n g g, n m p, n s p, n f p}}$

Otherwise (i.e. all groups are defective)<smiles></smiles>

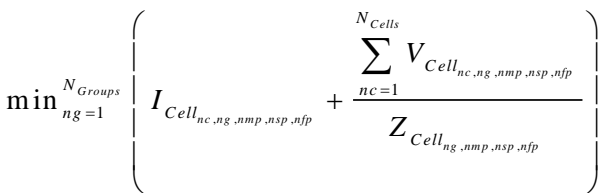

Where each group's current depends on the value of the impedance of its bypass diode.

d) For the short circuit default

The IV characteristic of the faulty module depends on the number of its good and defective groups existing, so if it contains at least one good group, then

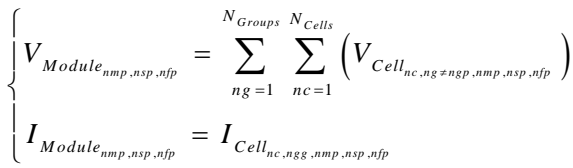

Otherwise (i.e. where all its groups are defective)

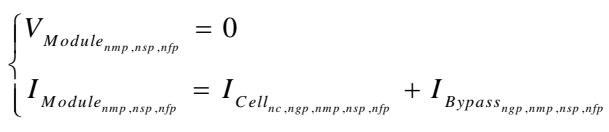

\section{III.2.3. At the level of the PV string}

a) For the reversed polarity default

Also for a faulty string, its voltage is dependent to its good groups and by the voltages in series addition law

$V_{\text {String }_{n s p, n f p}}=\sum_{n m=1}^{N_{\text {Modules }}} \sum_{n g=1}^{N_{\text {Groups }}} \sum_{n c=1}^{N_{\text {Cells }}} V_{\text {Cell }_{n c, n g \neq n n p, n m m, n s p, n f p}}$

By consent, the string's current is dependent to its faulty groups and by the currents in series addition law

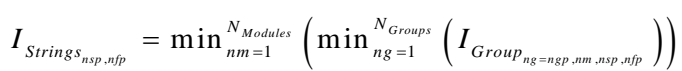

b) For the open circuit default 
The characteristic of the string which contains bypass diode open circuit is

$\left\{\begin{aligned} V_{\text {String }_{n s p, n f p}} & =\sum_{n m=1}^{N_{\text {Modules }}} \sum_{n g=1}^{N_{\text {Groups }}} \sum_{n c=1}^{N_{\text {Cells }}} V_{\text {Cell }_{n c, n g, n m, n s p, n f p}} \\ I_{\text {String }_{n s p, n f p}} & =I_{\text {Cell }} l_{n c, n g, n m, n s p, n f p}\end{aligned}\right.$

c) For the impedance default

The faulty string's voltage with bypass diodes impedances is constant regardless of the number of its defective diodes

$$
V_{\text {String }_{n s p, n f f p}}=\sum_{n m}^{N_{\text {Modules }}} \sum_{n g=1}^{N_{\text {Groups s }}} \sum_{n c=1}^{N_{\text {cells }}}\left(V_{\text {Cell }_{n c, n g, n n, n s p, n f p}}\right)
$$

But its current is dependent on the number of its defective and good groups, where if it contains at least one good group then

$$
I_{\text {String }_{n s p, n f p}}=I_{\text {Cell }_{n c, n g s, n n, n s p, n f p}}
$$

Else:

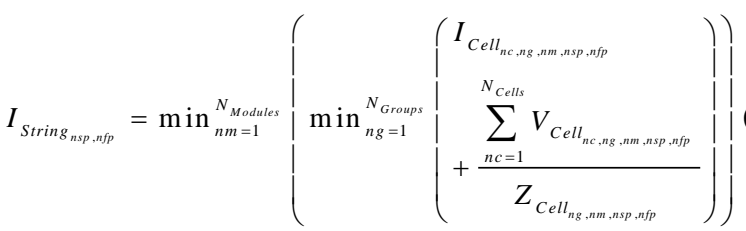

d) For the short circuit default

The string's characteristic if it contains at least one good group is



Otherwise, (i.e. all its groups are defective)

$$
\left\{\begin{array}{l}
V_{\text {String }_{n s p, n f p}}=0 \\
I_{\text {String }_{n s p, n f f p}}=\min _{n m=1}^{N_{\text {Modules }}}\left(\min _{n g=1}^{N_{G r u p s}}\left(I_{G \text { roup } n g, n n, n s p, n f p}\right)\right)
\end{array}\right.
$$

\section{III.2.4. At the level of the PV generator}

a) For the reversed polarity default

Because this default can reduce the voltage of the faulty strings, so the faulty generator's voltage is dependent to its faulty strings, but the generator's current is dependent to its good and faulty strings:

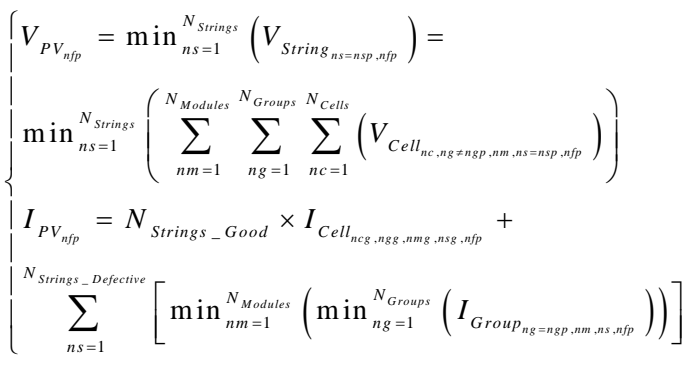

b) For the open circuit default

The generator's characteristic is dependent to its good and defective strings

$$
\left\{\begin{array}{l}
V_{P V_{n f p}}=N_{\text {Modules }} \times N_{\text {Groups }} \times N_{\text {Cells }} \times V_{\text {Cell }_{n c, n g, n n, n s, n, f p p}} \\
I_{P V_{n f p}}=N_{\text {Strings }} \times I_{\text {Cell }_{n c, n g, n m, n s, n f p}}
\end{array}\right.
$$

c) For the impedance default

The faulty generator's voltage is dependent to its defective and good strings' voltages, and the generator's current is dependent to its strings that contain at least one good group and that all its groups are defective

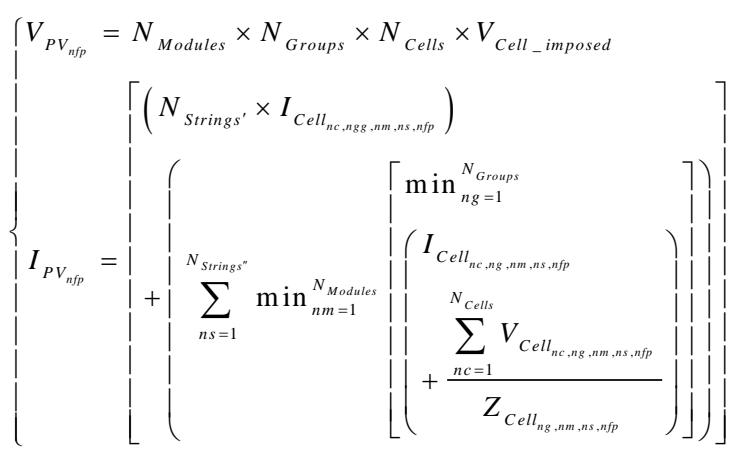

$N_{\text {Strings }}:$ strings contain at least one good group.

$N_{\text {Strings": }}$ strings all its groups are defective.

d) For the short circuit default

Finally, because this default can decrease the faulty strings' voltage, then the generator's voltage is dependent to its defective strings only, but the generator's current is dependent to its strings contain at least one good group and which that's all its groups are defective

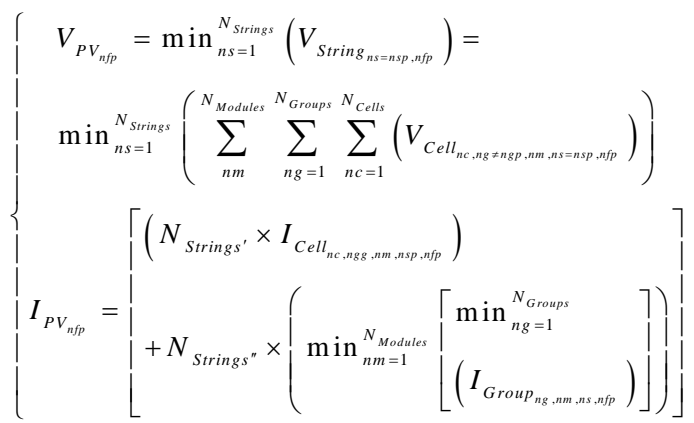

Where:

$N_{\text {Strings: }}:$ strings contain at least one good group.

$N_{\text {Strings"': }}$ strings all its groups are defective.

\section{III.3. Blocking diode defects}

\section{III.3.1. At the level of PV cell}

- If the string's current is not null and the string's opposite current is null (for short circuit and impedance defaults) 


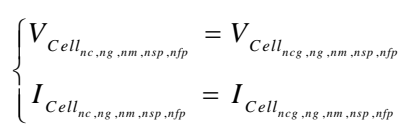

- If the string's cells' current is null and the string's opposite current is not null (for short circuit, impedance and reversed polarity defaults)

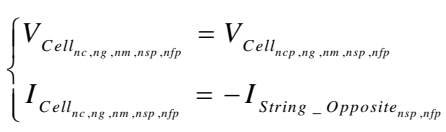

Where the Vcell is the voltage value provided by the passage of the string's opposite current - which is by a negative sign and according to the voltage of its string and its generator's voltage - by the photovoltaic cell.

- If the string's cells' current is not null and the string's opposite current is not null (for short circuit, impedance and reversed polarity) or for the blocking diode open circuit default

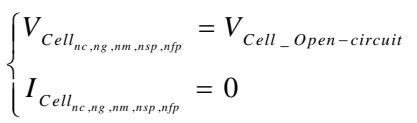

\section{III.3.2. At the level of PV group}

- If the string's current is not null and the string's opposite current is null (for short circuit and impedance defaults)

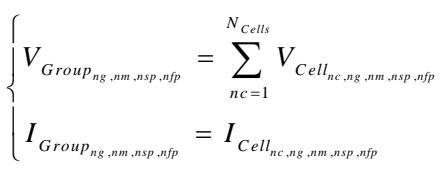

- If the string's cells' current is null and the string's opposite current is not null (for short circuit, impedance and reversed polarity defaults)

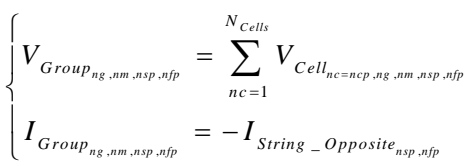

- If the string's cells' current is not null and the string's opposite current is not null (for short circuit, impedance and reversed polarity) or for the blocking diode open circuit default

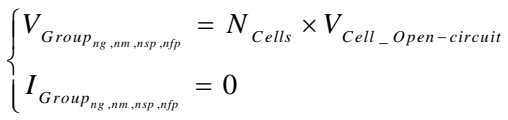

\section{III.3.3. At the level of PV module}

- If the string's current is not null and the string's opposite current is null (for short circuit and impedance defaults)

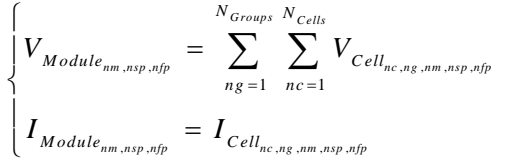

- If the string's cells' current is null and the string's opposite current is not null (for short circuit, impedance and reversed polarity defaults)

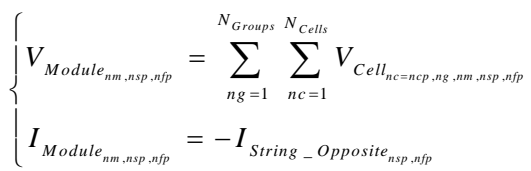

- If the string's cells' current is not null and the string's opposite current is not null (for short circuit, impedance and reversed polarity) or for the blocking diode open circuit default

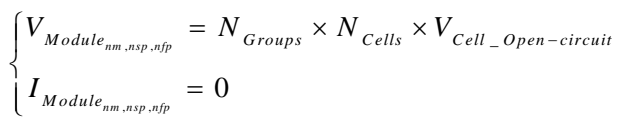

\section{III.3.4. At the level of PV string}

- If the string's current is not null and the string's opposite current is null (for short circuit and impedance defaults)

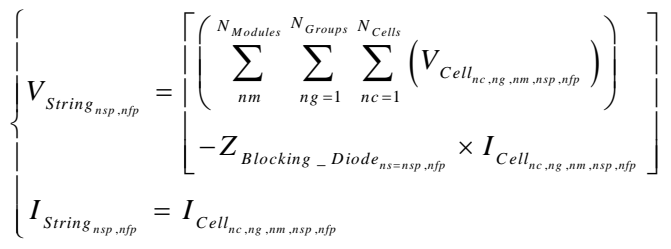

With $Z=0$ for short circuit default.

- If the string's cells' current is null and the string's opposite current is not null (for short circuit, impedance and reversed polarity defaults)

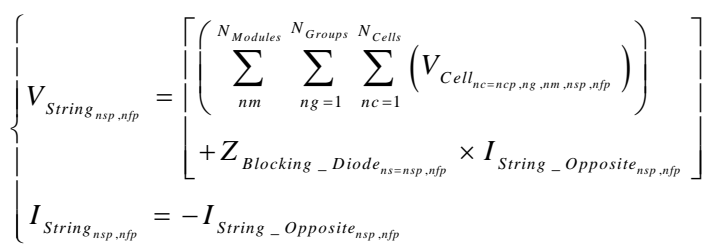

Where the opposite string's current is on the basis of the voltage of its string and its generator's voltage, and with $\mathrm{Z}=0$ for short circuit and reversed polarity defaults.

- If the string's cells' current is not null and the string's opposite current is not null (for short circuit, impedance and reversed polarity) or for the blocking diode open circuit default

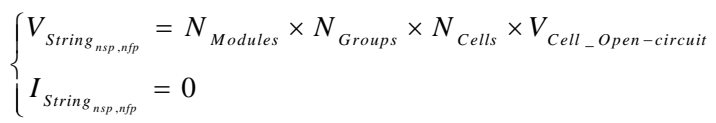

\section{III.3.5. At the level of PV generator}


The IV characteristic of the faulty generator is

- If the defective strings' currents are not zero and its opposite currents are zero (for short circuit and impedance defaults)

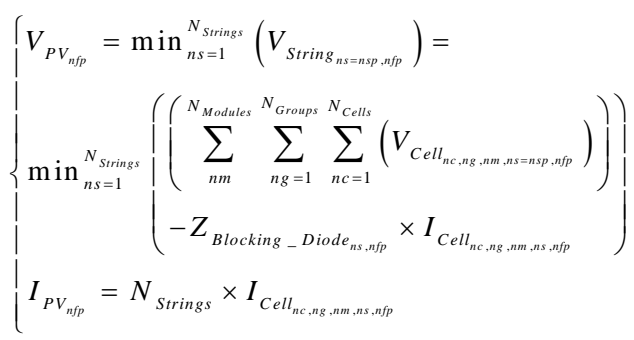

With $Z=0$ for short circuit default.

- If the defective strings' currents are zero and its opposite currents are not zero (for short circuit, impedance and reversed polarity defaults)

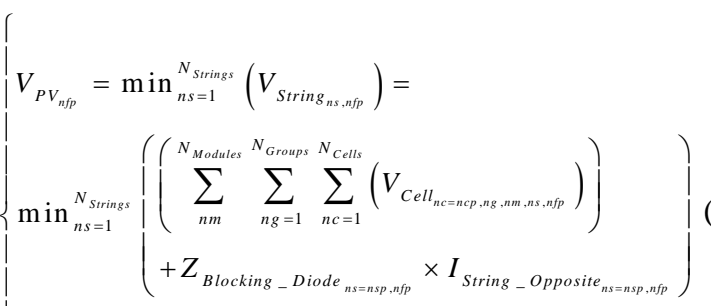

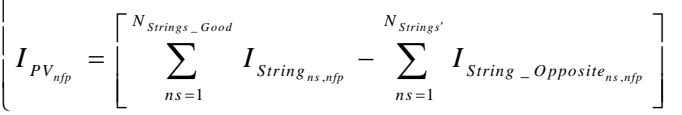

Where $\mathrm{N}_{\text {Strings }}$ : number of defective strings with provided current null and with $\mathrm{Z}=0$ for short circuit and reversed polarity defaults.

- If the defective strings' currents are not zero, its opposite currents are not zero and all the generator's strings are defective (for short circuit, impedance and reversed polarity) or for the blocking diode open circuit default

$\left\{\begin{array}{l}V_{P V_{n f p}}=N_{\text {Modules }} \times N_{\text {Groups }} \times N_{\text {Cells }} \times V_{\text {Cell_open-circuit }} \\ I_{P V_{n f p}}=0\end{array}\right.$

But if this faulty generator contains at least one good string

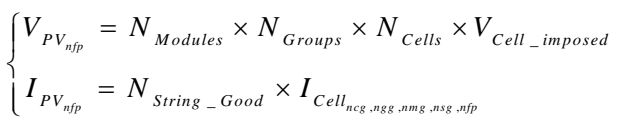

\section{Simulation and interpretation results}

The following fig. 3 to 14 presents the simulation of the proposed models for the mathematical modeling of the functioning of the PV generator, when subjected to the defaults reversed polarity, open circuit, impedance and short circuit. For testing the performance of these models, we studied theses cases which are:

\section{IV.1. For the reversed polarity default}

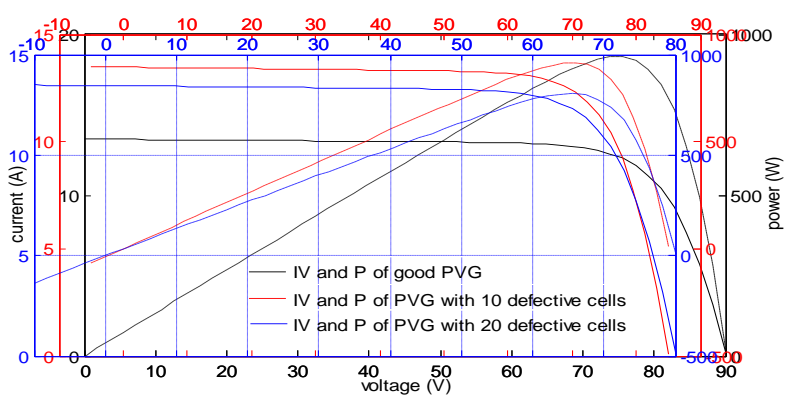

Fig3. IV \& $P$ of the PV contains cells reversed polarity.



Fig4. IV \& $P$ of the PV contains bypass diode reversed polarity.

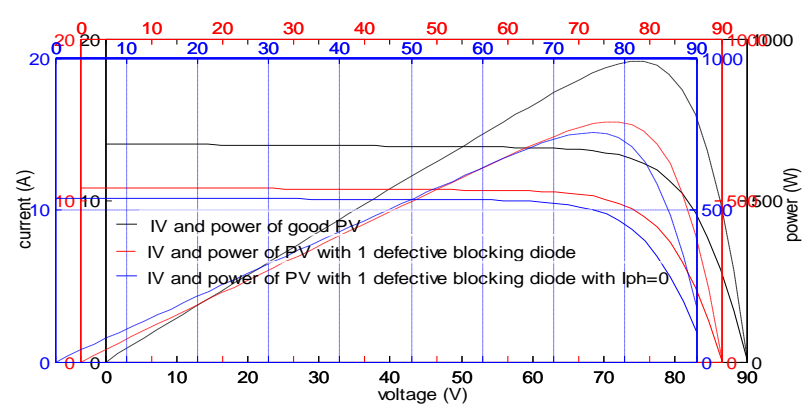

Fig5. IV \& $P$ of the PV contains blocking diode reversed polarity.

The existence of the two defects, cell reversed polarity or bypass diode reversed polarity in a generator make a remarkable degradation in its productivity, but only for the decrease in its value of voltage, because the cell reversed polarity mathematically provides a negative voltage at its terminals, and bypass diode in reversed polarity create a short circuit which can cancel outright the voltage of the group's cells which has protected. For cons, the default blocking diode reversed polarity, also it has an influence on the productivity of the generator, but not by reducing its voltage, on the contrary, this defect may increase the voltage of the entire string to the maximum, but he canceled outright the current supplied by this faulty string if its defective string's cells' current is not null, else this faulty string become as receiver.

\section{IV.2. For the open circuit default}

The two defects: cell open circuit and blocking diode open circuit in a generator makes a remarkable degradation in its productivity, because the existence of a single cell open circuit can cut the current flowing through its group and thus increase its voltage, and the 
existence of blocking diode open circuit can cut the current flowing through its string and thus increase its voltage. For cons, the open circuit fault at the bypass diode has no effect on the functioning of the generator, but if the cells grouped by this defective diode is in abnormal functioning, because the existence of any defect which can cut its current, as the cell open circuit, so the hybridization of these two faults can shut off the power supplied by the string, and therefore makes a very dangerous degradation in the productivity of the generator.



Fig6. IV \& $P$ of the PV contains cells open circuit.

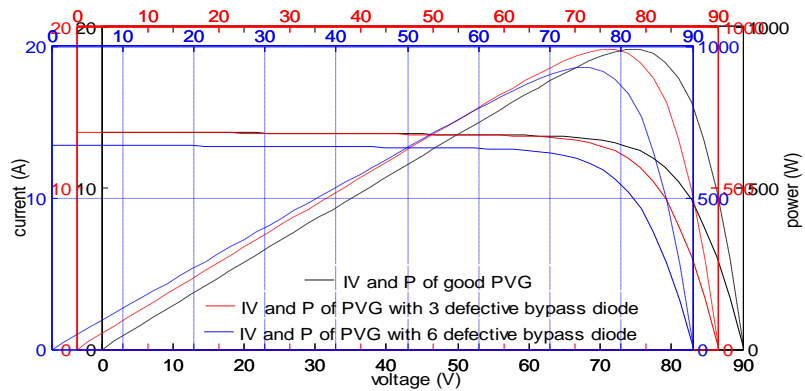

Fig7. IV \& $P$ of the PV contains bypass diode open circuit.

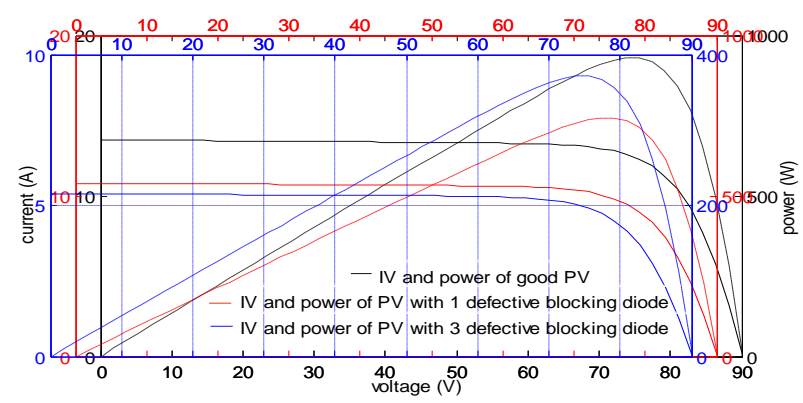

Fig8. IV \& $P$ of the PV contains blocking diode open circuit.

\section{IV.3. For the impedance default}

The two types of defects: cell impedance and blocking diode impedance, have the same influence on the function of the generator, because these two defects decreases its productivity, and by more these two types can increase the temperature of the defective components and create the default hotspots. Thus, this defect impedance and because it can cancel the current supplied by the defective cell, so it can cancel the current supplied by the entire string if all its cells are defective. Also for the default blocking diode in the case of the defective strings' currents are nulls, it can change the functioning of these faulty strings, and becomes as receivers, and also in the case of the defective strings' currents are not null, these faulty strings become as open circuit situation, because these defects are comments available the current flows in the both directions. By cons, the default impedance in the bypass diode has no influence on the voltage of the generator, but it increases the current supplied by the group grouped with this faulty diode in proportion to the decrease in its value of impedance. But this increase is danger, and it may change the characterization of the group and become as a receiver, provided a negative voltage across its terminals.

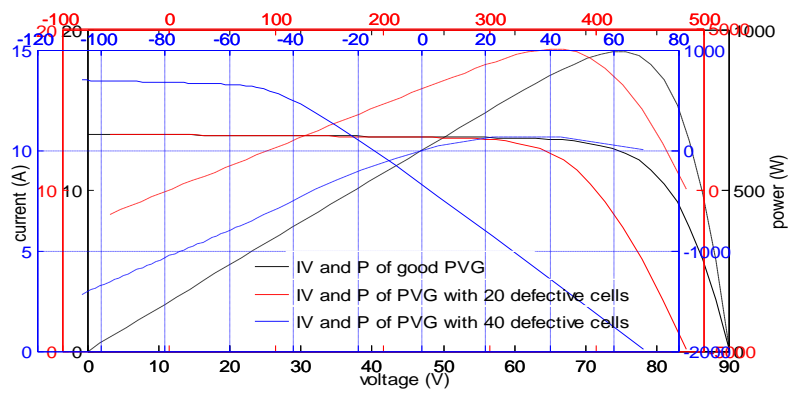

Fig9. IV \& $P$ of the PV contains cells impedance.

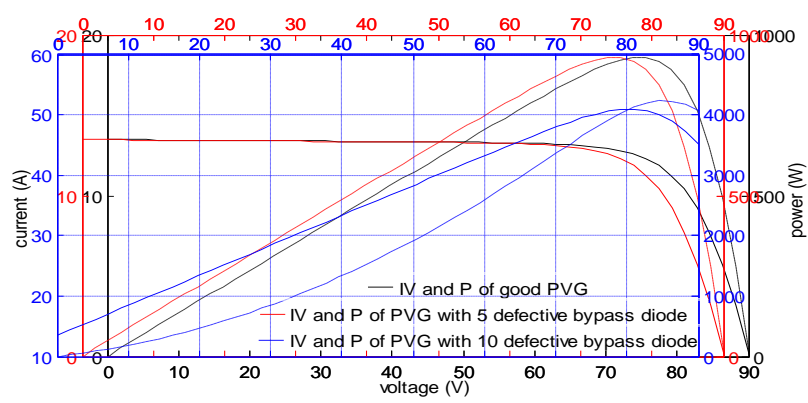

Fig10. $I V \& P$ of the PV contains bypass diode impedance.

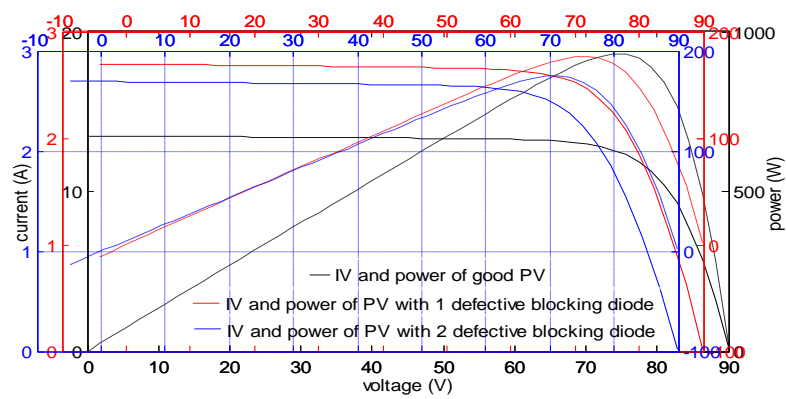

Fig11. IV \& $P$ of the PV contains blocking diode impedance.

\section{IV.4. For the short circuit default}

The default cell short circuit on the generator's productivity is significant and important, but it is better to default bypass diode short circuit, because for the first default, its appearance has only affected to the defective cell, but for the second default the existence of a bypass diode short circuit can cancel the voltage of all its cells which has gathered. By cons, the third type of this defect blocking diode short circuit has no influence on the 
functioning of the generator, where all its strings have the same voltage value, but if the string ended with this defective blocking diode has a minimum voltage and its cells' current is zero, so he became as a receiver, and he consumed - according to its voltage and the voltage of its generator - the current produced by the other strings which are with maximums voltages.

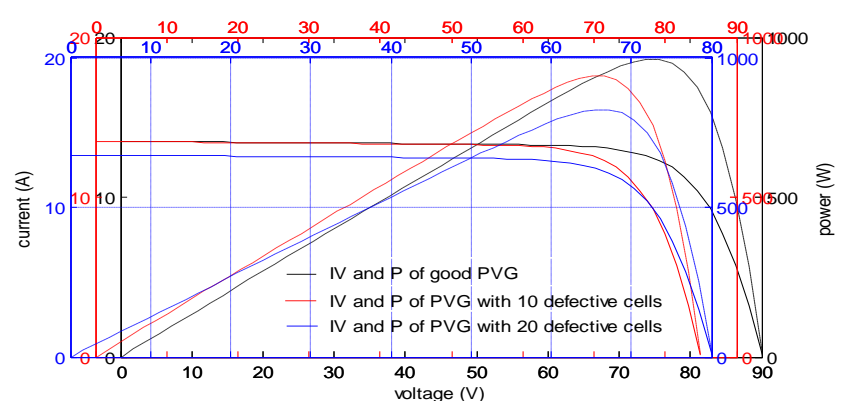

Fig12. IV \& $P$ of the PV contains cells short circuit.

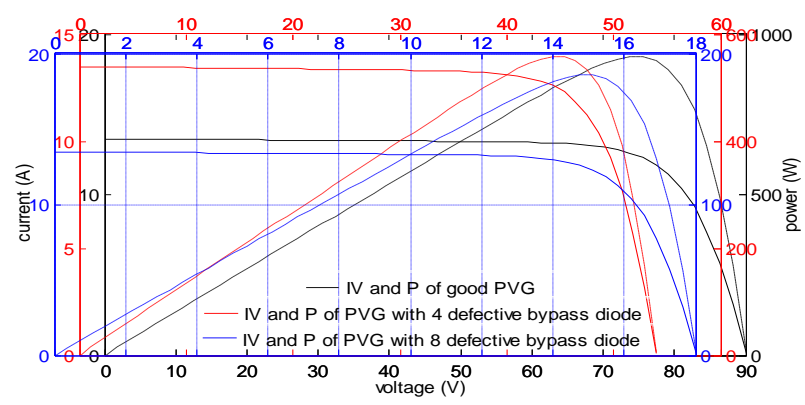

Fig13. IV \& $P$ of the PV contains bypass diode short circuit.

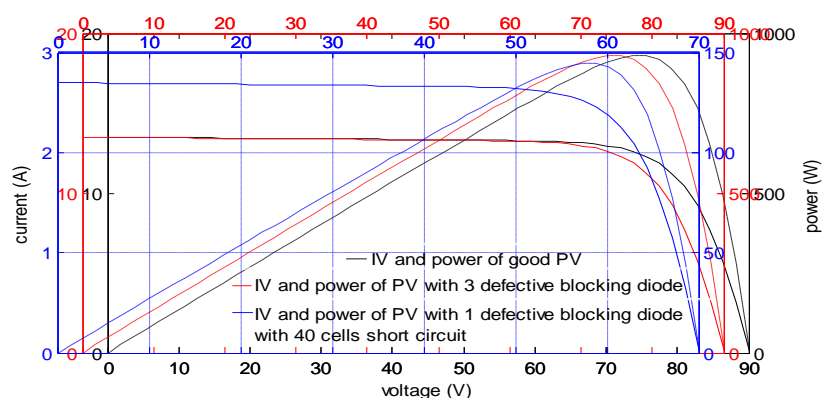

Fig14. IV \& $P$ of the PV contains blocking diode short circuit.

\section{Conclusion}

In this paper, we have proposed a new strategy for the mathematical modeling of the influence of the reversed polarity, open circuit, short circuit and impedance faults on the electrical characterization of the PV generator.

From the simulations and the interpretation results, the proposed methodology can provide an overview of the abnormal functioning of the generator, which can be used thereafter in his diagnosis. However, it is only to model the generator when it is subjected a maximum to one type of defect, on the same type of faulty elements, but for any quantity. Therefore, future work is to further improve these algorithms to model the generator when it's subjected to several types of defects on any elements.

\section{References}

[1] Junseok Song, Krishnamurthy V, Kwasinski A, Sharma R, Development of a Markov-Chain-Based Energy Storage Model for Power Supply Availability Assessment of Photovoltaic Generation Plants, IEEE Transactions on Sustainable Energy, Vol. 4, Issue. 2, pp. 491 - 500, April 2013.

[2] Young-Ho Kim, Young-Hyok Ji, Jun-Gu Kim, Yong-Chae Jung, Chung-Yuen Won, A New Control Strategy for Improving Weighted Efficiency in Photovoltaic AC Module-Type Interleaved Flyback Inverters, IEEE Transactions on Power Electronics, Vol. 28, Issue. 6, pp. 2688 - 2699, June 2013.

[3] Bin Gu, Dominic J, Jih-Sheng Lai, Chien-Liang Chen, LaBella T, Baifeng Chen, High Reliability and Efficiency Single-Phase Transformerless Inverter for Grid-Connected Photovoltaic Systems, IEEE Transactions on Power Electronics, Vol. 28, Issue. 5, pp. 2235 - 2245, May 2013.

[4] Ye Zhao, de Palma J, Mosesian J, Lyons R, Lehman B, Line-Line Fault Analysis and Protection Challenges in Solar Photovoltaic Arrays, IEEE Transactions on Industrial Electronics, Vol. 60, Issue. 9, pp. 3784 - 3795, Sept. 2013.

[5] Yongheng Yang, Blaabjerg F, Zhixiang Zou, Benchmarking of Grid Fault Modes in Single-Phase Grid-Connected Photovoltaic Systems, IEEE Transactions on Industry Applications, Vol. 49, Issue. 5, pp. 2167 - 2176, Sept.-Oct. 2013.

[6] Wu Yucai, Zhao Qian, Li Yonggang, Li Heming, Zhang Wenjing, Research Into Unbalanced Electromagnetic Force Resulting from Rotor Winding-Related Short Circuit of Turbine Generator, International Review on Modelling and Simulations (IREMOS), Vol. 8, Issue. 2, part A, pp. 608-615, April 2013.

[7] Ante Elez, Stjepan Car, Zlatko Maljković, A New Method for Inter-Coil Short Circuit Detection in Synchronous Machine Armature Winding, International Review on Modelling and Simulations (IREMOS), Vol. 7, Issue. 6, part A, pp. 6062-6069, December 2012

[8] Castilla M, Miret J, Sosa J.L, Matas J, de Vicuña L.G, Grid-Fault Control Scheme for Three-Phase Photovoltaic Inverters With Adjustable Power Quality Characteristics, IEEE Transactions on Power Electronics, Vol. 25, Issue. 12, pp. 2930 - 2940, Dec. 2010.

[9] Chen Min-you, Hu Gang, Zhai Jin-qian, High Impedance Fault Detection using Hilbert Transform and Least Square Support Vector Machine for Distribution Feeders, International Review on Modelling and Simulations (IREMOS), Vol. 7, Issue. 2, part B, pp. 4013-4020, April 2012.

[10] Ribeiro E, Cardoso A.J.M, Boccaletti C, Fault-Tolerant Strategy for a Photovoltaic DC--DC Converter, IEEE Transactions on Power Electronics, Vol. 28, Issue. 6, pp. 3008 - 3018, June 2013.

[11] ML. Eslami, R. Keivanian, Precise Modeling and Detection of High Impedance Faults in Microgrid System Based on Residual Current Harmonic Analysis, International Review on Modelling and Simulations (IREMOS), Vol. 7, Issue. 1, part B, pp. 35233531, February 2012.

[12] Cristaldi L, Faifer M, Rossi M, Toscani S, An Improved ModelBased Maximum Power Point Tracker for Photovoltaic Panels, IEEE Transactions on Instrumentation and Measurement, Vol. 63, Issue. 1, pp. 63 - 71, Jan. 2014.

[13] Wang T, Kamath H, Willard S, Control and Optimization of GridTied Photovoltaic Storage Systems Using Model Predictive Control, IEEE Transactions on Smart Grid, Vol. 5, Issue. 2, pp. 1010 - 1017, March 2014.

[14] E. Chiodo, A. Del Pizzo, L. P. Di Noia, D. Lauria, Modeling and Bayes Estimation of Battery Lifetime for Smart Grids Under an Inverse Gaussian Model, International Review on Modelling and Simulations (IREMOS), Vol. 8, Issue. 4, pp. 1253-1266, August 2013.

[15] Minh Y Nguyen, Yong Tae Yoon, Battery Modeling for Economic Operation of Energy Storage Systems in Electricity Markets, International Review on Modelling and Simulations (IREMOS), Vol. 8, Issue. 3, pp. 1000-1007, June 2013.

[16] Hejri M, Mokhtari H, Azizian M.R, Ghandhari M, Soder L, On the Parameter Extraction of a Five-Parameter Double-Diode 
Model of Photovoltaic Cells and Modules, IEEE Journal of Photovoltaics, Vol. 4 , Issue. 3, pp. 915 - 923, May 2014.

[17] Gan Zhou, Liping Zhan, Shihai Yang, Force and Torque Modeling for Linear Actuator Under State of Large Yaw Angle, International Review on Modelling and Simulations (IREMOS), Vol. 8, Issue. 2, Part A, pp. 690-695, April 2013.

[18] Lin Xu, Yang Han, Dynamic Modeling and Power Swing Damping Control (PSDC) of SVC Using ADPSS-Based Hardware-in-the-Loop (HID) Approach, International Review on Modelling and Simulations (IREMOS), Vol. 8, Issue. 2, Part A, pp. 305-313, April 2013.

[19] Ren Z, Yan W, Zhao X, Li W, Yu J, Chronological Probability Model of Photovoltaic Generation, IEEE Transactions on Power Systems, Vol. 29, Issue. 3, pp. 1077 - 1088, May 2014.

${ }^{1}$ Laboratory of Automation and Manufacturing, Batna Univerity, Rue Chahid Boukhlouf Batna Algeria.

${ }^{2}$ ISEN Brest, EA 4324 LBMS, Brest, France.

${ }^{3}$ University of Brest, EA 4325 LBMS, Rue de Kergoat, CS 93837 , 29238 Brest Cedex 03, France.
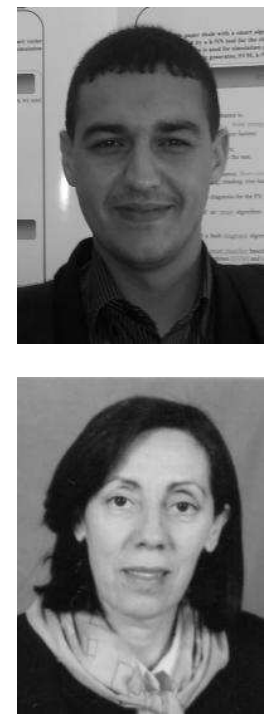

Wail REZGUI was born in N'gaous, Algeria, in 1987. He received his license in industrial engineering, industrial computer and Production option from Batna university between 2005- 2008 and his Master of Industrial Engineering, Industrial Computer and Production option, from university of Batna, between 2008- 2010. And finally hi registration Doctorate from university of Batna.

Leila Hayet Mouss was born in Batna, Algeria, in 1954. She received the B.Sc. degree in Electrical Engineering, in 1979, from the National Polytechnic School of Algiers, Algeria; the M.Sc. degree in Electrical and Computer Engineering, in 1982, from the ENSERB, France; and finally the Ph.D. degree also in Electrical and Computer Engineering, in 1985, Bordeaux University, France. After graduation, she joined the University of Batna, Algeria, where she is an Associate Professor of Electrical and Computer Engineering. Pr. Mouss is a member of New York Science Academy. She is the head of Automatic and Computer Integrated Manufacturing Laboratory. Pr. Mouss current research interests include industrial Diagnosis of production system using the artificial intelligence techniques in the LAP Lab (Laboratory of Automation and Manufacturing) at Batna, Algeria.

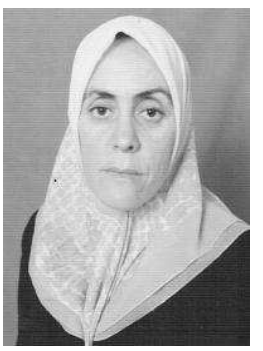

Kinza Nadia MOUSS was born in Batna, Algeria, in 1960. She received the B.Sc. degree in Electrical Engineering, in 1983, from the National Polytechnic School of Algiers, Algeria; the M.Sc. degree in Electrical and Computer Engineering, in 1984, from the ENSERB, France; and finally the Ph.D. degree also in Electrical and Computer Engineering, in 1986, Bordeaux University, France. After graduation, she joined the University of Batna, Algeria, where she is a Professor of Electrical and Computer Engineering. Pr. Mouss is the head of Computer Integrated Manufacturing and supply chain management group. Pr. Mouss current research interests include industrial Supply Chain Management, Production system and Computer Integrated Manufacturing
[20] Rahman S.A, Varma R.K, Vanderheide T, Generalised model of a photovoltaic panel, IET Renewable Power Generation, Vol. 8, Issue. 3, pp. 217 - 229, April 2014.

[21] Muhammad Ali, Azzam ul Asar, A. Rashid, Z. A. Zaidi, M. Jawad, Arshad Mehmood ,Amjad Ullah Hazrat Ali, Usman Shahid Khan, Smart Grid Intelligent Load Management Modeling and Analysis for Residential Colony Using FEDRP, International Review on Modelling and Simulations (IREMOS), Vol. 8, Issue. 1, Part B, pp. 262-267, February 2013.

[22] A. Siadatan, E. Afjei, H. Torkaman, Magnetic Modeling and Comprehensive Analysis of a Novel Seven-Layer Switched Reluctance Motor for High Torque per Volume Applications, International Review on Modelling and Simulations (IREMOS), Vol. 7, Issue. 6, Part A, pp. 6077-6083, December 2012.

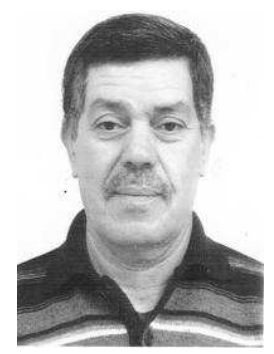

Mohamed Djamel Mouss was born in Batna, Algeria. He received his ingeniorat Electrical from ecole Nationale Polytechnique of Algiers in February 1982 and his Magister of electricity Industrial in 1989 of Batna university, after this hi obtained his Ph.D in Industrial Engineering in October 2006 from Batna University, and finally hi received the grade $\mathrm{HdR}$ Habilitattion led the research at University of Batna in November 2008.

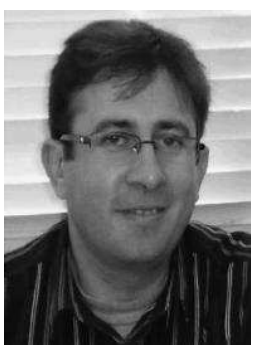

Yassine Amirat was born in Annaba, Algeria, in 1970. He received the B.Sc. and M.Sc. degrees in electrical engineering from the University of Annaba, Annaba, in 1994 and 1997, respectively. $\mathrm{He}$ is currently working toward the Ph.D. degree in wind turbine condition monitoring at the University of Brest, Brest, France. He is currently a Lecturer with the High Institute of Electronics and Numeric, Brest. His current research interests are the condition monitoring and the control of electrical drives and power electronics.

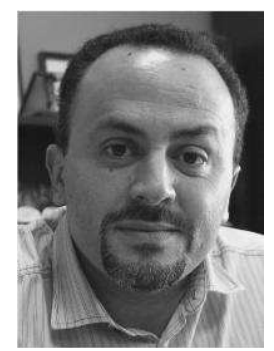

Mohamed El Hachemi Benbouzid (S'92-M'95-SM'98) was born in Batna, Algeria, in 1968. He received the B.Sc. degree in electrical engineering from the University of Batna, Batna, Algeria, in 1990, the M.Sc. and Ph.D. degrees in electrical and computer engineering from the National Polytechnic Institute of Grenoble, Grenoble, France, in 1991 and 1994, respectively, and the Habilitation à Diriger des Recherches degree from the University of Picardie "Jules Verne," Amiens, France, in 2000.

After receiving the Ph.D. degree, he joined the Professional Institute of Amiens, University of Picardie "Jules Verne," where he was an Associate Professor of electrical and computer engineering. In September 2004, he joined the University Institute of Technology (IUT) of Brest, University of Brest, Brest, France, as a Professor of electrical engineering. His main research interests and experience include analysis, design, and control of electric machines, variablespeed drives for traction, propulsion, and renewable energy applications, and fault diagnosis of electric machines.

Prof. Benbouzid is a Senior Member of the IEEE Power Engineering, Industrial Electronics, Industry Applications, Power Electronics, and Vehicular Technology Societies. He is an Associate Editor of the IEEE TRANSACTIONS ON ENERGY CONVERSION, the IEEE TRANSACTIONS ON INDUSTRIAL ELECTRONICS, the IEEE TransaCtions on Vehicular TEChNOLOGY, and the IEEE/ASME TRANSACTIONS ON MECHATRONICS. 